\title{
Chapter 3. Good Walls Make Bad Neighbours: The Dayak Longhouse as a Community of Voices
}

\section{Christine Helliwell}

Within the anthropology of Borneo, the Dayak longhouses found throughout the island have typically been depicted as each consisting of little more than a line of independent household apartments. It has consistently been argued, within this literature, that any apparent communality suggested by the fact that a number of apartments are joined into a single longhouse structure is an illusion; that each apartment is in fact a highly discrete entity. In this view, the 'independent' character of an apartment reflects a priority of household over community within Dayak social organization. Several ethnographers have taken this so far as to draw a parallel between the structure of a Dayak longhouse with its 'public' veranda and 'private' walled-off household areas — and that of an English-style street of semi-detached houses (see, for example, Geddes 1957:29; Freeman 1970:7, 1958:20).

For most anthropologists of Borneo, the household is the pre-eminent Dayak social unit (cf. King 1978:12-13). I have argued at length elsewhere that this view is mistaken with respect to at least some Dayak societies - in that there the primary social entity is not necessarily co-residential, and therefore does not properly constitute a 'household' — and that unwarranted stress on the 'household' can lead to serious misunderstandings concerning the character of Dayak social relations (see Helliwell 1990, 1991). My aim in this paper is a related one: to problematize the pervasive view within the Borneo ethnography of the Dayak household as profoundly independent from other households as well as from wider, more encompassing forms of social grouping. ${ }^{1}$

Gerai is a Dayak community of some 700 people, located in the northeast of the kabupaten (sub-province) Ketapang in the Indonesian province of Kalimantan Barat (West Borneo). ${ }^{2}$ Cultivation of rice in swiddens on the northern sunny slopes of hills is overwhelmingly the most important economic activity of Gerai folk, but most are not content to live at subsistence level and actively seek to create a little cash income. This is achieved through the sale of locally produced or obtained products (rubber, sawn wood, ${ }^{3}$ sandalwood), through providing services to the local population (carpentry services to neighbours and kin, translation and domestic services to the missionaries, bearer services to the traders), or through working at one of the nearby timber camps. 


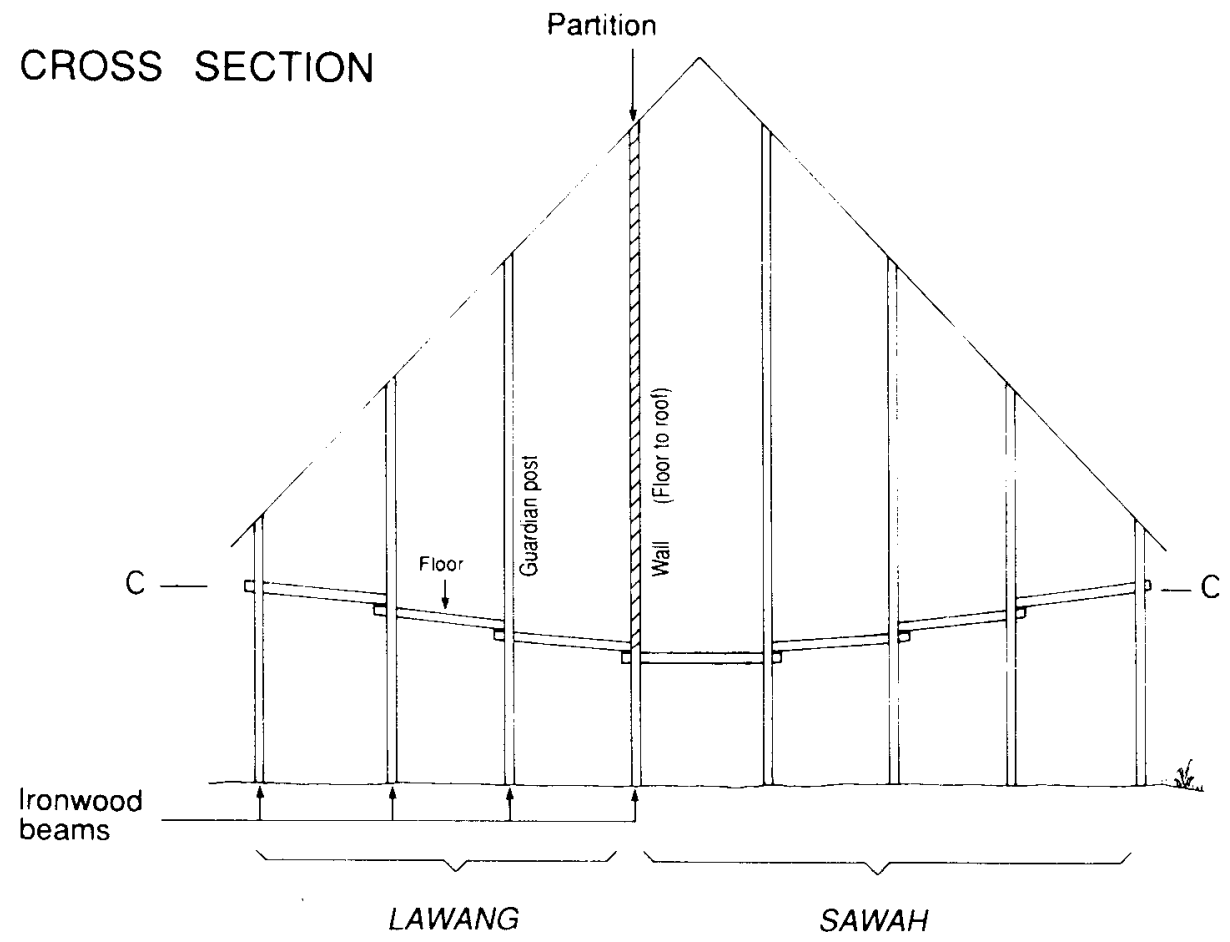

Figure 1. Gerai longhouse apartment in cross section

Twenty-five years ago the Gerai village proper consisted of four longhouses clustered together on the banks of a tiny stream. Of these, only two now remain. In the spaces where the other two once stood, and beyond, a plethora of free-standing dwellings has sprung up; these extend constantly the boundaries of the village. In 1986 the Gerai community contained 121 permanently inhabited dwellings, 106 of which were found in the village and fifteen outside. ${ }^{4}$ Only twenty-three of the 106 village dwellings were found in the two longhouses (fourteen apartments in one and nine in the other), the remaining eighty-three consisting of free-standing houses. It needs to be stressed at the outset of this paper then, that what is described here pertains to a traditional type of living space: one that is becoming increasingly irrelevant to Gerai Dayaks, as residence in their own free-standing houses becomes an important goal in the lives of most newly married couples.

The Gerai longhouse is laid out upon seven separate named levels, each of which is differentiated from the others according to what Gerai people term its guno nar (true, essential function). Although any level may be used for a variety of purposes at different times, it is the 'true function' of each which Gerai informants will supply and emphasize in any description of a longhouse apartment. The arrangement of these levels, and the essential function associated 
with each, is set out in Figure 1. As can be seen from the cross-section view the entire structure is covered by a soaring thatched or shingled roof: leaving no uncovered platform as exists, for instance, in both the Iban and Bidayuh Land Dayak longhouses. Within each apartment a wall stretches from floor to roof, dividing the apartment into an 'inner' household cooking, eating, and sleeping area which is partitioned off from the equivalent areas of those apartments on either side, and an 'outer' gallery area which is not partitioned. Into this separating wall of solid sawn planks a door is set, providing access from one section of the apartment to the other. The name for the inner section is lawang (door), although it is at least as frequently referred to as lem rumah (inside of the apartment). The outer section is termed ruang (platform, space), or more simply (and more usually) sawah (outside).

This basic division between an enclosed 'inner' area and an open 'outer' area is one that occurs in Dayak longhouses throughout Borneo. It has usually been portrayed as representing a separation between a 'private' household area and a 'public' community area. At first sight a description of the Gerai sawah and lawang as a 'public' and a 'private' space respectively, would seem to be borne out by Gerai Dayaks' own account of the differences between the two. If pressed, Gerai people will describe the sawah (outer area) as ramo, and the lawang (inner area) as yeng diret. Ramo means literally 'freely available to anyone', and refers to the fact that the sawah is an area where anybody from within the longhouse or the wider community may stroll, sit, weave, carve or whatever, without requiring permission from the actual owners of the apartment. Yeng diret translates literally as 'that which pertains to the self', and so appears to indicate that the lawang is an area that is not free to be used by anyone at any time. In fact its use by anyone other than members of the household to which it belongs is governed by strict rules of etiquette. If, for instance, the lawang is empty, or if the only inhabitants are sleeping, it may not be entered. Such a distinction between lawang and sawah does in fact seem very similar to the distinction made in Western society between the open 'public' street and the closed 'private' houses which it links together.

Yet, for the Gerai longhouse at least, such an understanding of this spatial division would constitute a serious distortion of both relations between the household and the wider longhouse community, and the role of the inner lawang space in the creation and reaffirmation of those relations. There is no doubt that the Gerai sawah corresponds to the social 'public' area found in other Borneo longhouses: like Dayaks elsewhere the Dayaks of Gerai come to this covered open space in the late afternoon and evening to share gossip, tobacco, betel-nut, or simply to stroll in the breeze. However, the implied view of the lawang that accompanies this - as a 'private' area reserved for the more exclusive use of the household - is much more difficult to sustain. As we shall see, forms of sociability take a different, less visible, form in the inner lawang area, which 
has led to their being ignored in the literature in favour of the more obvious conviviality of the outer sawah. In Gerai, lawang and sawah represent not an opposition between 'private' and 'public', but between 'inside' and 'outside' (as the very terms lem rumah ('inside of the apartment') and sawah ('outside') indicate). Implicit in this inside/outside opposition, I would suggest, is an opposition between not 'we, the household' (lawang) and 'they, the rest of the community' (sawah) but rather between 'we, the longhouse community' (lawang) and 'that, the world out there', of which we may also at times be a part, (sawah). In other words, the spatial separation parallels a division not within the longhouse community but between that community and those without it: between 'we' and 'other'.

This understanding is supported by the Gerai description, already noted, of the difference between these two spaces: of the outer sawah as ramo (freely available to anyone) and the inner lawang as yeng diret (that which pertains to the self). For in Gerai the meaning of the word diret extends beyond the basic sense of 'self' to mean also 'we/us including the person spoken to'. That the term should encompass these two meanings in English is no accident, for Gerai people tend not to distinguish between oneself and those with whom one is carrying out any particular activity at a particular moment. ${ }^{5}$ Describing the lawang as a space that is yeng diret, then, designates it as pertaining to 'we' (a group of selves engaged together in some particular activity), without excluding the conception of that space as one over which household members are able to exercise particular rights vis-à -vis the community at large. The term yeng diret not merely encompasses but, indeed, implies both meanings. The activity which binds us together through our shared engagement in it is our longhouse residence, and the very particular mode of social interaction in which this residence necessarily implicates us.

This portrayal of the nature of lawang space fits most comfortably with the clear identification, among Gerai Dayaks, of the sawah space as that of strangers and outsiders. Thus, although it most often functions as an area of easy community sociability, the guno nar (true, essential functions) of two of its four levels are to do with Malay guests to the longhouse. Gerai informants specify (as seen in the floor plan, Figure 2) that the 'true' uses of the sadau sawah and the paléper sawah ('outside' equivalents of the sadau and the paléper, which are both found in the lawang) are as a sleeping place and a cooking place respectively for Malay visitors to the longhouse. The Dayaks of Gerai, like many other Dayak groups, tend to define themselves ethnically in opposition to Malays. ${ }^{6}$ So deep is this opposition that Gerai folk will often use the term reng Melayu (Malay) to mean simply non-Dayak. ${ }^{7}$ The association of the outer sawah with Malays is thus a clear expression of its status as an area for 'others', as opposed to the inner lawang which is 'our' space. 


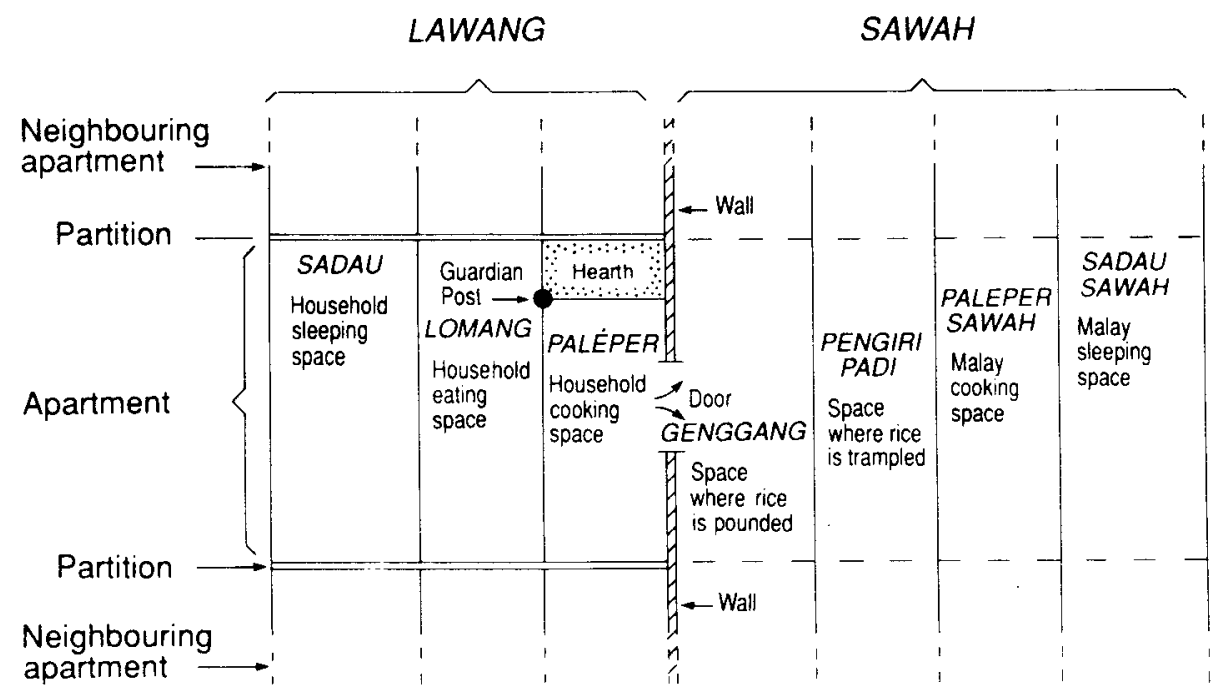

Figure 2. Gerai longhouse apartment floor plan

In past times, Gerai Dayaks were under the control of the Malay raja based in Sukadana, some 80 kilometres away on the coast. Although its location far from a river deep enough to be used for transport meant that Gerai had only very rarely received visits from the raja's emissaries, in 1986 Gerai myth and oral history remained full of references to them, and to the raja himself. Unlike Dayaks from other longhouses or villages who, during the days of Malay control, had arrived at the longhouse as either friends or enemies (and so could be treated accordingly), Malays had come as neither. Their loyalty and service to the raja demanded that they be treated with care and respect in order to avoid the raja's wrath, but the nature of Gerai relations dictated then as now that they be seen as a different order of being, one which refuses pork and rice wine (both prized by Gerai people) and engages in an incomprehensible and highly amusing set of practices with respect to its deities. It is partly because of these taboos that Gerai Dayaks deem it most sensible to banish Malays as guests to the outer sawah levels, where they are least likely to be affected by Dayak customs.

But the practice reflects a more deeply held conception of the lawang as 'our space' and the sawah as 'the space of others' than is accounted for simply through reference to Dayak wishes not to offend. Thus informants told me that in the past a Malay was not permitted, on pain of death, to enter a lawang, although Dayak strangers were generally invited to do so. The degree to which this outer area is regarded as a Muslim (that is, Malay) eating and sleeping area was revealed in a statement made to me during my early days in the longhouse, in response to my suggestion that I might build myself living quarters on the sawah area of one of the apartments. Longhouse residents were disapproving: 'Only people 
who don't eat pork should eat and sleep out on the sawah. You are one of us it wouldn't feel right to have you living out there'.

This not only points up the conception of the sawah as a Malay area but also demonstrates the degree to which Gerai Dayaks conceive of the world as divided essentially between 'us' and 'those who don't eat pork' (that is, Malays). Another response made to the same suggestion emphasizes the gleeful Dayak joke which is involved in the banishment of their erstwhile masters to the outer veranda space. In order to dissuade me once and for all from building on the longhouse sawah, it was pointed out that each household's pigs are kept immediately beneath this section. As living quarters such an area would therefore be noisy and foul-smelling. How much more so for Malays, to whom pigs are so unclean that contact with them of any kind is strenuously avoided!

It is not my intention to go into detail about the nature of the sawah space and how it is distinguished from the lawang of an apartment. It is sufficient for my purposes here to have demonstrated that the lawang/sawah division in Gerai constitutes a conceptual opposition between the longhouse community and those outside it, rather than one within that community. For the remainder of this paper I focus on the lawang. The nature of this 'inner' space, and of the community interaction that takes place within it, has been seriously neglected in the anthropological literature on Dayak societies. Yet examination of these is crucial if one is to gain an understanding of the linkages between household and community in Gerai.

\section{Lawang Construction and Lawang Space}

In line with the overwhelming emphasis within the Borneo literature on the household as the most important unit of social organization most ethnographers of Dayak societies have been content to describe a longhouse simply by outlining a single apartment. The implicit assumption in this approach has been that the nature of the longhouse as a whole may be grasped by the reader through a simple imaginary aggregation of a number of these units. ${ }^{8}$ The danger here is that in conceptualizing any longhouse primarily in terms of discrete constituent components, any relationships that operate between apartments - and especially those occurring in the private 'inner' setting — may be overlooked. The Gerai longhouse, for instance, certainly does comprise a number of separate widthwise units each associated with a single household. But it at the same time - and equally as importantly - constitutes a single lengthwise entity in space. To isolate a single apartment and describe the relationships that operate across its spatial levels, tying them together into one unit, would be to neglect the relationships that flow from one apartment to another, tying them together into a community. While these community ties may at first sight appear to be sustained largely through easy interaction between the members of neighbouring apartments in the open sawah space, they achieve much greater frequency and 
intensity within the closed-off lawang space, shielded there from the eyes and ears of the larger world.

The private, as opposed to communal, ownership of the materials which go to make up any one longhouse apartment is a feature of Borneo longhouses which has been stressed relentlessly in the literature. In this respect the longhouses at Gerai are no exception. Each individual household owns the nails, planks, strips of bamboo, lengths of rattan, units of thatch and so on, which together comprise its longhouse apartment. Such a pattern has often been taken to indicate a set of property relations similar to those which operate in the West, and to provide further evidence both for the importance of individualism in Dayak culture and for the separation of any one Dayak household from those others surrounding it. However, there is no necessary link between ownership of the materials that together go to make up an apartment, and exclusive rights or control over the finished structure and over the space which it circumscribes. In the Gerai longhouse, while the household has certain rights over its own apartment space, such space is at the same time an inseparable part of a larger community space, and therefore subject also to the rights of neighbours. No Gerai Dayak would ever claim (or indeed wish to claim) that any part of a longhouse apartment is radically isolated from those on either side of it in the way that the proverbial Englishman wishes to claim that his home is his castle. This holds as true for the inner walled-off lawang as it does for the outer open sawah. To describe any part of a Gerai longhouse apartment in terms of a fixed dichotomy between 'private' and 'public' would thus be to ignore the complex and shifting balance achieved between household rights and community rights with respect to that apartment as a whole.

It has long been recognized by anthropologists and sociologists that the arrangement of domestic space is closely linked to the nature of the domestic and social relationships lived within that space. Therefore the analysis of spatial arrangements is seen as potentially able to provide important clues to the indigenous conceptions of those relationships. ${ }^{9}$ Most such analyses have focused on the formal division of space and how this accords with (or perhaps masks) patterns of social organization and/or deeper conceptual schemes. In examining lawang space I am concerned to avoid a focus on formal spatial arrangements and to concentrate instead on the way this space is lived and experienced in everyday life.

Closer examination in these terms of the wall separating the lawang of one apartment from that next to it is revealing. The character of this wall is crucial for any discussion of the longhouse as a lengthwise entity, for it is this which divides that entity up into its constituent units. It is normally made of flimsy pieces of bark and other materials propped up against each other in such a way as to leave gaps of varying sizes, through which dogs and cats can climb, people 
can hand things back and forth, and at which neighbours can stand while they chat together. Like everything else in the longhouse this wall is always owned by one of the two households whose apartments it delimits (by the household that built its apartment first). But in practical terms it is shared by both, and it marks off the space of the second as much as it does the space of the first. The dividing wall includes in itself the notion of the next apartment at the same time as it demarcates the apartment to which it belongs. In physical terms it is highly permeable: through it move a variety of resources in both directions.

But the character of the partitions between neighbouring lawang is important not only for the relations that it promotes between an apartment and those on either side of it but also for fostering an uninterrupted sociability from one end of the longhouse to the other. The very permeability of the partitions - their makeshift and ricketty character - allows an almost unimpeded flow of both sound and light between all the apartments that together constitute a longhouse.

This flow of sound and light is crucial, for I argue that the Gerai longhouse community as a whole is defined and encircled more by these two things than by anything else. I recall, while living in the Gerai longhouse, writing letters back to Australia in which I constantly referred to the longhouse as a 'community of voices', for I could think of no more apt way to describe the largely invisible group of which I found myself to be a part. Voices flow in a longhouse in a most extraordinary fashion; moving up and down its length in seeming monologue, they are in fact in continual dialogue with listeners who may be unseen, but are always present. As such they create, more than does any other facet of longhouse life, a sense of community. Through the sounds of their voices neighbours two, three, four or five apartments apart are tied into each other's world, into each other's company, as intimately as if they were in the same room.

During my first two months in the longhouse, sharing the apartment of a Dayak household, I could not understand why my hostess was constantly engaged in talk with no one. She would give long descriptions of things that had happened to her during the day, of work she had to do, of the state of her feelings and so on, all the while standing or working alone in her longhouse apartment. To a Westerner, used to the idea that one's home stops at its walls, and that interaction beyond these involves a projection of the voice or of the self, which makes impossible the continuation of normal domestic chores, her behaviour seemed eccentric, to say the least. It was only much later, on my second field trip, that I came to realize that the woman's apparent monologues always had an audience, and that they were a way of affirming and recreating the ties across apartments that made her a part of the longhouse as a whole rather than a member of an isolated household. In addition, I recognized with time that she was almost certainly responding to questions floating across apartment 
partitions that I, still bewildered and overwhelmed by the cacophony of sound that characterizes longhouse life, was unable to distinguish.

Eventually I too came to be able to separate out the distant strands that were individual voices, which wove together magically in the air and flowed through the spaces of separate apartments. These were never raised as the dialogue moved through four or even five partitions, but their very mutedness reinforced the sense of intimacy, of membership in a private, privileged world. Such conversations were to be taken up at will and put down again according to the demands of work or sleepiness: never forced, never demanding participation, but always gentle, generous in their reminder of a companionship constantly at hand. For me, even in memory they remain utterly compelling: the one aspect of longhouse life that distinguishes it most clearly from the Western world to which I have since returned.

Not only sound but light as well flows from one apartment to another particularly at night, when the longhouse is demarcated against the surrounding blackness by the tiny lights glowing up and down its length. In explaining why they sow the seeds of a plant bearing red flowers along with their rice seed, Gerai Dayaks told me that once in bloom, the flowers serve as 'lights' or 'fires' for the growing rice: 'Just as human beings in the longhouse at night like to see many lights around them and so know that they have many companions, in the same way the rice sees the flowers at night and does not feel lonely' ${ }^{10}$ At night in the longhouse one is aware of the presence of companions by the glow of their lights and their hearths. If a light is not showing in any apartment, its absence is an immediate source of concern and investigation. On at least three occasions when I developed a fever in the late afternoon, and by evening was too ill to get off my mat and light my lamp, it was the darkness in my apartment that brought people anxiously to my aid. 'Why is your apartment in darkness, Tin?' was always the first query, to be taken up immediately in the conversation flowing to further parts of the longhouse. If there was no reply, within seconds neighbours would be pushing open the door.

While the lawang partitions may demarcate space within which particular household rights hold sway then, that space is also a crucial element in a larger community space within and across which sound and light must be able to move. For it is this movement which constantly reaffirms to both the household itself, and to those on either side of it, its status as a part of the longhouse, and thereby of the community of neighbours that is enclosed within it. Gerai people themselves are perfectly well aware of the significance of the flimsiness of this wall for cross-apartment relationships. As a result, my attempts, in the early days of residence in my own apartment, to create for myself more privacy by filling in some of the gaps in my side walls with strategically-placed pieces of cardboard and bark, were viewed with extreme disapproval by my neighbours. 
They interpreted such behaviour as an assertion of independence at the expense of community membership. In response they so frequently 'accidentally' knocked askew my assorted pieces of filler that I eventually resigned myself to living with the holes.

While I have concentrated here on the phenomenological aspects of cross-lawang relationships in Gerai, the character of a lawang, as subject to community rights, is also asserted explicitly within Gerai customary law. I shall elaborate on this with respect to two of the obligations that owners of apartments have to the wider longhouse community. Firstly, a representative of the household must light a fire in the apartment hearth every five or six days. Gerai Dayaks are adamant that not lighting a fire with such regularity is a crime against one's neighbours rather than against the spirit world. For this reason, they say, such a lapse is not punished by the supernatural, but in the past demanded litigation against the head of the household. Such litigation would normally be carried out by those neighbours whose apartments adjoined that of the delinquent, and the largest share of any ensuing fine would be paid to them. Gerai people told me in 1986 that nowadays neighbours are reluctant to sue one another on such grounds, yet I noted that this obligation is still strictly adhered to by longhouse members. The requirement to light a fire in the hearth every few days is quite explicitly to do with the need for the all important api (light, fire) in an apartment. A dark unlit apartment creates an uncomfortable fission in the smooth flow of communality from one end of the longhouse to the other. An apartment without light, without fire, is most essentially an apartment without human beings; it is this lack which dismays the members of neighbouring apartments. The dark empty space to right or left detracts from their sense of belonging to a larger community - from their sense of being a part of the 'we in here' as opposed to the 'that out there'. Those households which stay at their farm huts for extended periods, while they prepare their rice fields for planting or weed the growing crop, are spoken of with passion as jat (bad, wicked): 'They don't care about their neighbours, they just want to live alone at their rice fields'. Significantly, when a household does decide to move as a whole to live at its farm hut for a time, it asks one of its two neighbouring households, rather than a household related by kinship, to take on the task of lighting a fire in the hearth every six days. Longhouse neighbours, then, assume the crucial responsibility for one another's continuing de facto presence in the community during any absence. The necessity to maintain this presence is a central tenet of longhouse life.

Secondly, the members of a household must demonstrate their love and respect for their apartment by taking care of it. In the recent past, if they failed in this undertaking, it was again the neighbouring households which sought compensation for the neglect of the apartment adjoining their own. Still today, any signs that an apartment is not being cared for (such as holes in the roof or 
floor) are cause for community gossip and for shame on the part of its inhabitants. Gerai people say that an apartment that is buro' (meaning literally 'rotten', but in this case 'falling apart, run down') is essentially an apartment without people. Its presence, therefore, constitutes a denial of the rights of neighbours to live next to an apartment that is inhabited.

In summary, the space delimited by the lawang construction in Gerai is not 'private' space, radically separated from the similar spaces beyond its partitions in the way that the space within an English semi-detached house would normally be. The Gerai longhouse is built in a style that both asserts the autonomous status of each of the individual households holding formal rights over the separate apartments of which it is composed, and generates the embeddedness of those groups in the broader longhouse community. The very construction of a longhouse apartment, and the way it articulates with those on either side of it, both encodes and, indeed, generates relationships of interdependence between the separate households that together comprise the Gerai longhouse community: 'Biarpun banyak lawang, pokok-e sebetang ja'. ('Although there are many apartments, basically there is only one trunk').

\section{Lawang Behaviour: Public or Private?}

Not merely resources, light and sound are shared across the permeable boundaries between Gerai longhouse apartments. The human gaze also passes through that wall, and thus lawang structure both encodes and gives rise to a particular form of social control. ${ }^{11}$

Socially acceptable forms of behaviour may be enforced within any lawang in Gerai by means of a sliding scale of sanctions, ranging from community disapproval to the imposition of fines. In particular, each household is ritually linked through its hearth to a 'parental' household known as its bungkung (root, origin). The head of a bungkung apartment is morally, and in some cases legally, responsible for what takes place in such affiliated apartments. In cases of seriously unacceptable behaviour — such as the maltreatment of a child — he will intervene in the affairs of the household and demand a change in behaviour. If his advice is ignored, he may be compelled to take legal action against the offender(s).

But the monitoring of behaviour which might lead to the application of such sanctions is made possible by the very permeability of the barriers separating apartments. The fact that the lawang is so open to the scrutiny of neighbours places those inhabiting it under much greater pressure to conform than would be the case if lawang were truly 'private' areas. For example, Gerai values place enormous emphasis on the importance of sharing between households, such that when any household obtains a relative abundance of a resource - and particularly of food resources other than rice - it is expected to share it out 
among neighbours and close kin. Thus, a longhouse resident who hears her neighbour return from a hunting trip or from checking fish traps, from gathering fruit or collecting vegetables, moves to the partition, and, with a greater or lesser degree of surreptitiousness (depending on the nature of the relationship between herself and her neighbour), examines the booty that has been brought in. Concomitantly, at any time that she herself arrives home with (or without) game, fish, vegetables and so on, she knows that the neighbour's gaze will be upon her.

In the Anglo-American anthropological writings on Dayak societies there is little information on the means by which social norms may be affirmed and social control asserted over deviant individuals, or on the role played by longhouse apartment structure in this process. As a result, Dayaks have sometimes been portrayed in this literature as rather wayward and contrary, specific individuals concurring with social norms only when the whim takes them, and only if it is in their own best interests to do so (see, for example, Geddes 1957:20-26). A consideration of the gaze as a technique ensuring the functioning of social control in Gerai is instructive in this regard, for Gerai Dayaks would appear to be as individualistic and even as 'anarchistic' ${ }^{12}$ as any others in the ethnographic region.

Knowledge of the gaze of others among Gerai longhouse members is a powerful force for conformity. In the case of the Gerai person who returns to the longhouse with a plentiful haul of meat, fish, vegetables, or whatever, awareness of being under observation is generally enough to persuade him/her to resist any temptation to miserliness, and instead to share out the goods. In not sharing, such a person would risk the networks by which he/she receives as well as gives, for neighbours will quickly tell others of his/her lack of generosity. Not to share is also to risk general opprobrium and the jat nar (very bad, wicked) label: an unpleasant prospect in such a small community.

There are of course households in Gerai - and increasingly more of them today, with the growing importance of a cash economy - which are prepared to take these risks in order to retain a greater portion of whatever resources they may obtain for their own use. However, it is important to note that these people inevitably move out of the longhouse and build independent free-standing dwellings. Due to the very structure of the longhouse with its highly permeable boundaries between separate lawang, longhouse living becomes incompatible with a reluctance to share resources.

But the gaze of neighbours is able to focus not only on the ways in which a household is dividing up its resources, but also on the more general actions and behaviours of apartment inhabitants. Just as goods, light and sound flow freely back and forth so, too, do advice, opinions, soothing words. I was once in a friend's apartment several doors down the longhouse from my own, when a 
heated argument between husband and wife broke out in the apartment next door. My friend immediately moved to the partition, arriving in time (as she told me later) to see the husband, squatting on the floor in the eating section, kick out and strike his wife on the leg. 'What's going on?' my friend enquired, while the wife burst noisily into tears. The husband explained that in the heat of argument his wife had snatched the plate that he was eating from and emptied its contents through the bamboo-slatted floor. He had kicked her in response. My friend, assured that one wrong had balanced another and that no major row was about to break out, returned to sit next to me. Her presence had calmed the situation and prevented any escalation of events.

The behaviour that takes place within any particular Gerai lawang, then, is subject to an extraordinary degree of interference by the wider longhouse community. This is mainly through the presence of the gaze, which acts as both a surveillance technique, by means of which information may be gathered, and an enforcer of conformity in its own right through people's awareness of their visibility. Just as the knowledge that others may be watching at any moment makes it almost certain that households will share their resources with one another according to social norms so, too, does it ensure that most of the time the members of any particular lawang behave towards one another in ways that are generally considered acceptable. The construction of the lawang itself, far from mirroring any household's wish for independence, actively promotes community interference into, and control over, the lives of household members. The wish to escape community pressure was the main reason given to me for their impending move by a number of younger couples, who intended to build free-standing dwellings, and so leave the longhouse. In addition, the two households at the very ends of the longhouse (one at each end) in which I lived in 1985 and 1986 were far more reluctant to share with neighbours and to take part in general forms of sociability than any other groups resident in that longhouse. Because they each adjoined only one apartment, their activities were much less open to scrutiny, and hence much less amenable to community pressure than were those of other households.

Yet, it must be stressed that a recognition of the community's ability to enforce certain types of behaviour within any particular lawang space does not constitute a denial of the rights over that space held by members of the household themselves. In particular, the household has rights over use of the lawang space: in the absence of any household members, only very close and trusted friends or kin may enter that space. Even these people should enter under such circumstances only for a very specific purpose, such as to borrow a utensil. More prolonged visits to an empty lawang, or visits by those who are socially more distant, may lead to accusations of intention to steal or, worse, of intention to introduce malevolent spirits into the hearth. Disappearance of household items or illness of a group member following such a visit may well lead to litigation. 
In addition, apartment inhabitants who spend a great deal of time examining the goings-on in neighbouring apartments are said themselves to be jat (wicked, bad), and a variety of motives may be attributed to their actions in this respect: ranging from the wish to steal goods to the intention of bewitching or poisoning their neighbours. Ironically, it is the constant possibility of surveillance that keeps in check excessive use of such a technique. There is in fact a code of etiquette operating in Gerai, which any person should follow when gazing into a neighbouring apartment. This specifies intention (the reasons why one is looking at that particular moment) and notification (the act of indicating to one's neighbour that he or she is under observation) as the two most important factors in distinguishing 'when and how one should look' from 'when and how one should not look'. One may peer or glance casually for just a moment, as already outlined, but if the gaze is of longer duration, its social approvability will be assessed in accordance with these two factors. One may never stand and stare into an apartment whose inhabitants are sleeping or not present, for instance, since the gaze lacks the element of notification. Similarly, it is said that one should never stand and watch a neighbour's misfortune, such as a household fight or a person's grief, unless one has sincere, good intentions in doing so. Apartment inhabitants have rights to privacy within their own lawang, then, even while that space constitutes part of a broader community space.

It is precisely because of the constant affirmation of its status as community space - its very openness to the public voice and gaze - that the lawang of an apartment is almost the only place in the village where one may be alone without inviting suspicion and public discussion of one's motives and actions. Gerai people in general dislike being alone, and rarely see a point to it. Thus it is well-nigh impossible to be alone in open parts of the village. A lone person sitting working in the sawah section of the longhouse, for instance, will soon attract others to his or her side, whose arrival might well be prefaced with 'You poor thing - sitting there all alone!'. In the same way, someone who needs to carry out a task away from the village will normally seek a companion, and the sight of a lone person in the jungle thus attracts attention and questions. In particular, a married woman headed alone into the jungle, even if she has a perfectly legitimate task to perform such as foraging for bamboo shoots or collecting firewood, automatically invites suspicions about her possible engagement in an adulterous liaison (the jungle being the usual location for such liaisons). If a man is seen in the area, they may both be subject to litigation. In a longhouse apartment lawang, on the other hand, it is possible, easily and naturally, to be alone - simply because one is recognized as never being alone.

The relaxed openness of a lawang to a neighbour's eyes and ears means that only extraordinary behaviour inside it makes a deep impression on those without. Otherwise the presence of its inhabitants is largely taken for granted: they are part of the background audience which always surrounds one while in a 
longhouse. Glancing into a lawang, unless done for a specific purpose, such as inspecting a newly-arrived load of foodstuffs, involves nothing more than a casual orientating of oneself vis-à -vis the members of that other household. As such it does not impinge on the rights of those others over that space. For my own part, I found that my longhouse neighbours were highly sensitive to my own needs for 'privacy', so long as they were able to locate my presence in the apartment from time to time.

It is this recognition of the individual apartment as inevitably a part of the larger community - such that it is impossible to discuss it in terms of the 'public' and 'private' realms found in our own streets of separate houses - which renders problematic any attempt to depict the Gerai longhouse either as an aggregate of separate dwellings or as a unified community. Residence in a longhouse means that one can belong to both household and community at once, or to either at different times. This is why it is possible to be alone in an apartment through the very act of not being alone. ${ }^{13}$

\section{Concluding Remarks}

For the Dayaks of Gerai, as for most Dayak groups, household autonomy is a central cultural value, and there is no doubt that in Gerai (as elsewhere) certain features of longhouse structure are linked to this fact. Yet, examination of the spatial arrangements within the Gerai longhouse does not support a view of the Gerai household as an isolated and inward-turning entity. Rather, it indicates its embeddedness in the larger longhouse community of which it is a part. Emphasis on the apartment's orientation widthwise as part of a single longhouse structure should not be taken as a denial of its lengthwise identity as a separate unit within that structure. The apartment is both of these at the same time, just as its member household is both autonomous and yet highly dependent on the longhouse community of neighbours. Freeman's (1970:129) implication that the Iban longhouse must be viewed as either (but not both) a collection of discrete entities or as unified longhouse group assumes a series of conceptual dichotomies - between 'self' and 'other', 'private' and 'public' and so on - which do not fit comfortably with the Gerai notion of the interdependence of person, household and community. Indeed, these conceptual oppositions look dangerously similar to those generated within Western thought by opposition between person and society.

It is at least possible, that the Gerai longhouse is not unique in this respect. It seems likely that the inordinate emphasis on the priority of household within the literature on Dayak societies is the result of an understandable preoccupation among an earlier generation of ethnographers with questions concerning the capacity of Dayak forms of social organization to generate stable and enduring social relations (cf. Appell 1976:4-6). Freeman's inspired demonstration of the role of the Iban household in this respect, established once and for all the 
credentials of cognatic societies as no less viable than their unilineal counterparts. But at the same time it bequeathed to the anthropology of Dayak societies both an underemphasis on the importance of wider community groupings and a discourse in which jural considerations hold sway at the expense of how institutions are lived and experienced.

The Gerai longhouse division into lawang and sawah, and the nature of the relationships between separate lawang spaces, only becomes comprehensible when viewed in the context of the permeability of the boundaries separating a lawang from those on either side. Such interstitial zones are as important to an understanding of the nature of domestic space as is the actual inner arrangement of that space. The American poet Robert Frost implicitly recognized this point when he asserted that in his own American rural community 'good fences make good neighbours'. ${ }^{14}$ In this respect many Western domiciliary arrangements contrast sharply with those found in the Gerai longhouse. There it is not the walls which make good neighbours, but the gaps and tears that occur within them. It is these that allow an easy flow of communality along the length of the longhouse. In this flow lies both the threat of community disapproval and sanctions and the promise of resources and companionship but a spoken word away.

\section{References}

Appell, G.N.

1976 Introduction. In G.N. Appell (ed.) The societies of Borneo: explorations in the theory of cognatic social structure, pp.1-15. Washington: American Anthropological Association.

1978 The Rungus Dusun. In Victor T. King (ed.) Essays on Borneo society, pp.143-171. Oxford: Oxford University Press for the University of Hull.

Avé, J.B.

1972 Kalimantan Dayaks - introductory statement. In Frank Lebar (ed.) Ethnic groups of insular Southeast Asia, Vol. 1, pp.185-187. New Haven: Human Relations Area Files Press.

Bourdieu, Pierre

1977 Outline of a theory of practice. Cambridge: Cambridge University Press.

Freeman, J.D.

1958 The family system of the Iban of Borneo. In Jack Goody (ed.) The developmental cycle in domestic groups, pp.15-52. Cambridge: Cambridge University Press for Department of Archæology and Anthropology, Cambridge University.

1970 Report on the Iban. London: Athlone Press. 
Geddes, W.R.

1957 Nine Dayak nights. Melbourne: Oxford University Press.

Harrison, Robert

1976 Hamlet organization and its relationship to productivity in the swiddenrice communities of Ranau, Sabah, Malaysia. In G.N. Appell (ed.) The societies of Borneo: explorations in the theory of cognatic social structure, pp.87-109. Washington: American Anthropological Association.

Helliwell, Christine

1990 The ricefield and the hearth. PhD thesis, The Australian National University, Canberra.

1991 Many voices: rhetoric and ethnographic understanding in a Borneo Dayak community. In Andrew Pawley (ed.) Man and a half: essays in Pacific anthropology and ethnobiology in honour of Ralph Bulmer, pp.241-248. Auckland: The Polynesian Society.

Hudson, A.B.

1970 A note on Selako: Malayic Dayak and Land Dayak languages in Western Borneo. Sarawak Museum Journal 28:301-318.

King, Victor T. (ed.)

1978 Introduction. In Victor T. King (ed.) Essays on Borneo societies, pp.1-36. Oxford: Oxford University Press for the University of Hull.

1979 Ethnic classification and ethnic relations: a Borneo case study. Hull: Centre for South-East Asian Studies, University of Hull (Occasional Papers No. 2).

Lebar, Frank M. (ed.)

1972 Ethnic groups of insular Southeast Asia, Vol. 1. New Haven: Human Relations Area Files Press.

Mauss, Marcel with Henri Beuchat

1979 Seasonal variations of the Eskimo: a study in social morphology (translated with forward by James J. Fox). London: Routledge \& Kegan Paul.

Miles, Douglas

1976 Cutlass and crescent moon: a case study of social and political change in Outer Indonesia. Sydney: Centre for Asian Studies, University of Sydney.

Sather, Clifford

1976 Kinship and contiguity: variation in social alignments among the Semporna Bajau Laut. In G.N. Appell (ed.) The societies of Borneo: explorations 
in the theory of cognatic social structure, pp.40-65. Washington: American Anthropological Association.

1978 The Bajau Laut. In Victor T. King (ed.) Essays on Borneo society, pp.172-192. Oxford: Oxford University Press for the University of Hull.

\section{Notes}

This paper was originally presented in October 1987 as part of a seminar series on concepts of space in Asia held in the Department of Prehistory and Anthropology at The Australian National University. I wish to register my gratitude to Douglas Miles (who organized that series) for persuading me to participate in it. The written version has been read by many people: thanks to, in particular James J. Fox, Barry Hindess, Douglas Miles, Nicholas Thomas and Michael Young for their careful scrutiny and comments. I also wish to thank Michael Jackson for his initial suggestion of several fruitful lines of enquiry which are taken up here. This paper is also published in Oceania 62, 1992 and is reproduced here with permission.

\footnotetext{
${ }^{1}$ Some accounts of Dayak societies have emphasized the embeddedness of the household in wider social groupings, but they are unusual. See especially Sather $(1976,1978)$ on the 'household cluster' among the Bajau Laut; Harrison (1976) on the 'hamlet' among the Dusun of Ranau; and Appell (1978) on, particularly, the longhouse among the Rungus Dusun.

2 Following Hudson (1970), I would classify Gerai Dayaks (who neither distinguish themselves by any ethnic name nor affiliate themselves with any Dayak group) as a 'Malayic Dayak' people, descending from Proto-Malay-speaking ancestors who crossed to Borneo before Islam reached South-East Asia. This categorizes them linguistically with the Iban and other Ibanic-speaking peoples, although many aspects of their social organization and culture are more strongly reminiscent of the 'anarchist' and diffident Land Dayak traditionally thought to have inhabited this entire region (see, for example, Avé (1972:186); also Lebar's (1972) unpaginated map of the ethnic groups of Borneo).

Fieldwork in Kalimantan Barat was carried out between March 1985 and February 1986, and between June 1986 and January 1987. It was funded by a PhD research scholarship from The Australian National University.

3 Several men in the community now own chainsaws.

4 Eight households cluster into two tiny extra-village hamlets, while a further seven live in ramshackle huts at their rice fields.

5 I must make it clear that I am not arguing in favour of a Lévy-Bruhlian (for instance) depiction of 'primitive societies' as lacking individuals: individual consciousness having been swamped by a larger social consciousness completely dictating thought and action. Such a view comes out of a Western dichotomization of individual and community that does not occur in Gerai.

6 Among anthropologists the problem of distinguishing between the ethnic identities of Dayaks and Malays has often been seen as a very complex one, since Dayak groups which adopt Islam and form separate communities after their conversion generally are known as Malays, even though they may live as part of Dayak communities with pagan Dayaks and share many of their traditions and practices (see Avé (1972: 185); King (1979:28-34); also Miles (1976)). The Dayaks of Gerai do not share the anthropologist's difficulty here: the adoption of Islam, and particularly of the taboos on eating pork and drinking alcohol that accompanies it, means that one has 'become Malay'.

7 Although, if pressed, they will of course distinguish between Malays, Chinese, Dutch and so on.

8 Appell is an exception. His 1978 article stresses the linkages existing along a longhouse and states that the longhouse is not considered 'merely an aggregate of member families' (1978:160).

9 Mauss (1979) was perhaps the first to engage in such an analysis with his classic study of Eskimo dwellings. More recently Bourdieu's (1977) scintillating analysis of Kabyle domestic arrangements has
} 
demonstrated the power of such arrangements to mediate between core cultural schema and social practice.

10 Gerai Dayaks believe that rice shares a descent line with human beings. Because of this it must be treated as if it were human, and so a number of features of the layout of a rice field parallel human life within a longhouse.

11 Douglas Miles has pointed out that the movement of the gaze is linked to the flow of light already described.

12 Geddes uses the term 'anarchist' to refer to the Bidayuh Land Dayak (for example, 1957:20, 21).

13 Geddes (1957) notes that longhouse residence has 'solved a great human problem - how to be independent and yet never be isolated ... In the longhouse it is possible to be an individual and yet lead a cosy life of company' (p.32).

${ }^{14}$ In one of his most well-known poems, entitled 'Mending Wall'. 



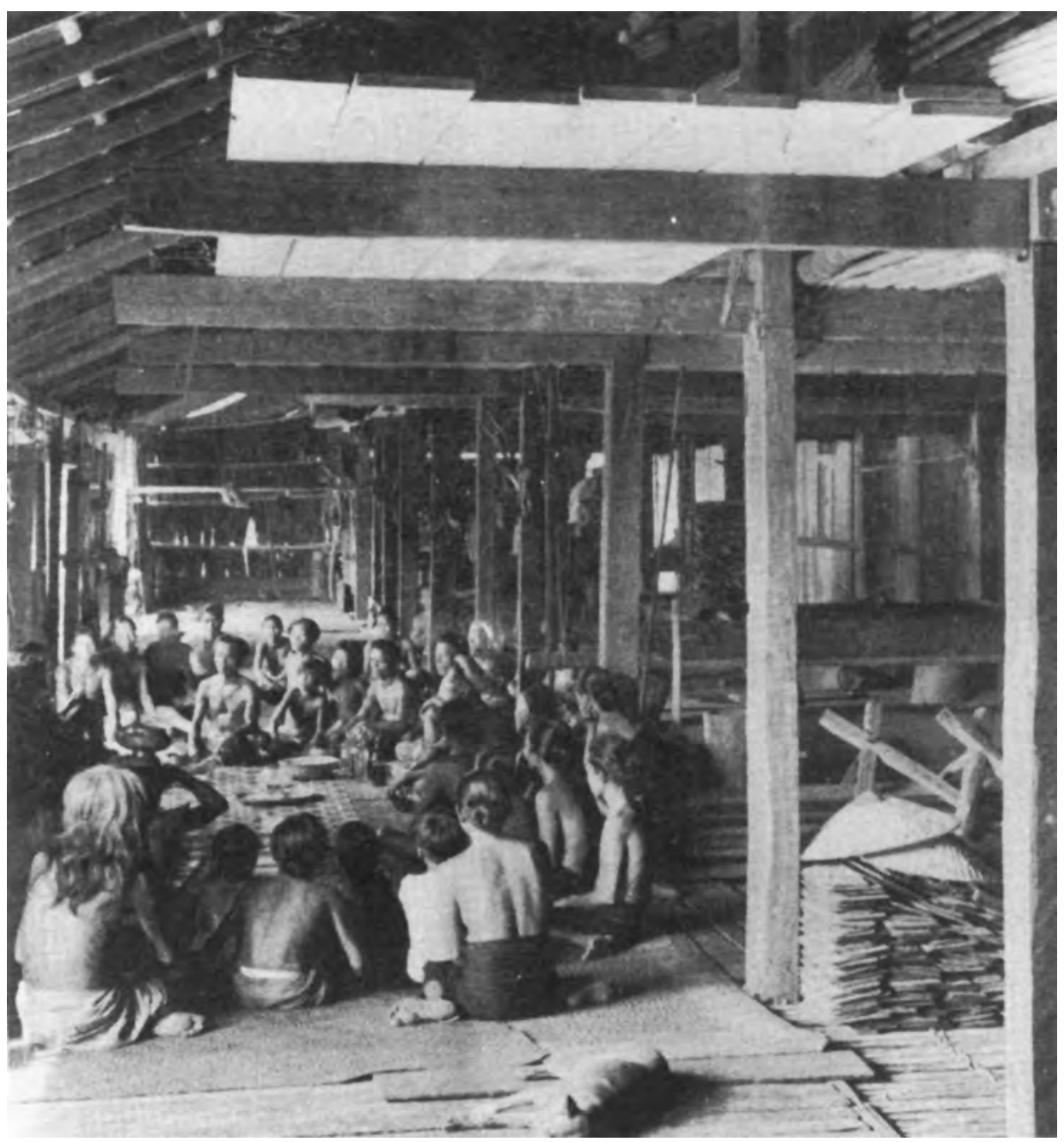

The ruai, or communal area of the Iban longhouse. 